\title{
Factors influencing subcolony colonization and persistence in a colonial seabird, the common murre Uria aalge
}

\author{
Stephani G. Zador ${ }^{1,2, *}$, Julia K. Parrish ${ }^{1}$, André E. Punt ${ }^{1}$ \\ ${ }^{1}$ School of Aquatic and Fishery Sciences, Box 355020, University of Washington, Seattle, Washington 98195, USA \\ ${ }^{2}$ Present address: NOAA Alaska Fisheries Science Center, 7600 Sand Point Way NE, Bldg 4, Seattle, \\ Washington 98115-0070, USA
}

\begin{abstract}
Within an established seabird colony the choice of where to settle can be influenced by site fidelity, natal philopatry or public information. To form a new colony individuals must choose before philopatry has been established or public information is available. We explored the intracolony dynamics of common murres Uria aalge, specifically the formation and persistence of new subcolonies within a larger colony complex composed of numerous contiguous groups. We investigated the effects of (1) environmental conditions that influence the prey base, (2) predator disturbance, and (3) population size change on colonization patterns and modeled the persistence of recently colonized murre subcolonies as a function of their starting population sizes. Marine environmental conditions in the 2 winters previous to the breeding season had more influence than demographic and predator factors on whether subcolony colonizations occurred. The number of murres in the first year of colonization helped to explain the persistence of the subcolony, regardless of the amount of available nesting habitat within a subcolony area. Subcolonies that started out larger were more likely to persist. The results support the theory that the proportion of the entire murre population that attempts to breed in a given year is higher in years with favorable environmental conditions prior to the breeding season. Increased knowledge of murre colony formation may help scientists and managers understand the potential for recolonizations after colony extirpations or better predict the success of management actions such as social attraction or habitat modification.
\end{abstract}

KEY WORDS: Common murre $\cdot$ Uria aalge $\cdot$ Population dynamics $\cdot$ Top-down forcing $\cdot$ Bottom-up forcing

\section{INTRODUCTION}

Colonial breeding is seen across diverse taxa (Danchin \& Wagner 1997) and is common in marine mammals and seabirds (Robson et al. 2004, Antolos et al. 2006). The evolution of coloniality in seabirds has received much attention, although it is still an unresolved topic (Wittenberger \& Hunt 1985, Clode 1993, Buckley 1997, Danchin \& Wagner 1997, Brown \& Brown 2001). Primary benefits of colonial breeding include predator avoidance (Anderson \& Hodum 1993), social facilitation (Pius \& Leberg 2002) and an increased ability to find food (Davoren et al. 2003), although there can be costs manifested in intraspecific aggression (Stokes \& Boersma 2000) and parasite transmission (McCoy et al. 2005).

Within an established colony the choice of where to settle can be influenced by previous use of the nest site by the individual (site fidelity) or by its parents (natal philopatry), or by unrelated individuals (public information). Many seabirds exhibit strong site fidelity. For example, 91 to $99 \%$ of common murres Uria aalge return to breed in the site in which they bred the previous year (Ainley et al. 2002). Bird species that exhibit natal philopatry, such as thick-billed murres $U$. lomvia, often return to their colony of birth to breed with $>50 \%$ 
of them nesting within $3 \mathrm{~m}$ of their hatching site (Steiner \& Gaston 2005). On the other hand, blacklegged kittiwakes Rissa trydactyla evaluate the quality of potential breeding sites by observing the numbers and reproductive success of presumably unrelated birds breeding there (public information, see review in Valone \& Templeton 2002) and choose whether or not to settle accordingly (Danchin et al. 1998). Similarly, very low density Arctic skua Stercorarius parasiticus colonies attract fewer recruits than do high density, productive colonies (Phillips et al. 1998), whereas only colony size, not reproductive success, was found to influence immigration in lesser kestrels Falco naumanni (Serrano et al. 2004). However, these mechanisms operate only when a colony is already occupied. To form a new colony birds must choose before philopatry has been established or public information is available. Thus, additional factors may influence colony establishment.

Common murres (hereafter referred to as murres) nest densely within available spaces on cliff ledges and cliff tops, such that a colony is often composed of groups of birds (subcolonies) separated by unsuitable habitat such as rock walls too steep for nesting. Murres begin to breed at age 6 to $7 \mathrm{yr}$, but may prospect for potential breeding sites for several years before settling (Halley et al. 1995, Ainley et al. 2002). Experienced breeders return to high quality sites that are often physically protected by walls and/or surrounded by neighboring murres, whereas lower quality or firsttime breeders tend to change sites or nest in sites located at edges of the colony (Harris et al. 1996, 1997, Kokko et al. 2004).

Reproductive success tends to be predictably high in high-quality, experienced breeders, as murres can buffer the effects of a moderately poor food supply by adjusting their foraging behavior (Burger \& Piatt 1990). In contrast, there is evidence that lower quality or prospecting murres may defer breeding when environmental conditions are not favorable (Halley et al. 1995, Crespin et al. 2006a), thus influencing the proportion of an entire population attempting to breed each year. Demographic factors, such as immigration and productivity (Oro \& Ruxton 2001), and predation pressure (Martinez-Abrain et al. 2003) may also influence attempts to breed, especially in new areas. We hypothesized that the colonization patterns of newly occupied subcolonies may be sensitive to annual fluctuations in factors that influence the proportion of birds attempting to breed because newer subcolonies may be composed of lower-quality or first time breeders (Hario 1982, Harris et al. 1997).

Murres are well studied relative to many other seabird species. Much attention has been paid to the population dynamics of established murre colonies
(Hatchwell \& Birkhead 1991, Sydeman 1993, Crespin et al. 2006a,b), and productivity and population trends are well documented at the level of individual colonies for which long time series of data exist (Ainley \& Boekelheide 1990, Harris et al. 1992, Harris \& Wanless 1995). Less attention has been paid to inter-colony dynamics and formation of new colonies (Ainley et al. 2002). In this paper, we explore intra-colony dynamics, specifically the formation and persistence of new subcolonies within a larger colony complex composed of numerous contiguous groups of murres. Colonization and persistence of new subcolonies are each independent processes driven by different factors (MartinezAbrain et al. 2003); thus, we use murres to investigate which factors may influence patterns of subcolony colonization and persistence. First, we test what factors representing annual environmental conditions, predator disturbance and population size change may influence subcolony colonization patterns in following years. We then model the persistence of recently colonized murre subcolonies as a function of their starting population sizes with and without taking into account the amount of available nesting habitat within the subcolony area.

\section{MATERIALS AND METHODS}

Tatoosh Island $\left(48^{\circ} 24^{\prime} \mathrm{N}, 124^{\circ} 44^{\prime} \mathrm{W}\right)$ is a 6 ha complex of flat-topped rock islets $0.6 \mathrm{~km}$ off the northwest tip of Olympic Peninsula of Washington State, USA. The murre population on Tatoosh Island expanded rapidly during the 1980s following the automation of the lighthouse and concomitant loss of human inhabitants (Paine et al. 1990). Murre nesting areas expanded on open cliff tops, until increasing predator disturbance due to increasing numbers of bald eagles Halieetus leucocephalus led to abandonment of the largest exposed cliff-top subcolony in the early 1990s (Parrish \& Paine 1996). Since then there has been a redistribution of nesting murres, with greater proportions of murres nesting on cliff ledges than on cliff tops and approximately 3500 are estimated to be in attendance each year.

Murres on Tatoosh Island nest in groups on cliff tops and cliff ledges around the island (Parrish 1995). Subcolonies are defined as contiguous nesting groups from which a murre would need to fly or jump to reach the next nesting area, and are separated by approximately 1 to $30 \mathrm{~m}$. The estimated mean $( \pm \mathrm{SE})$ distance between each subcolony and its closest neighbor is $6.1 \pm 1.1 \mathrm{~m}$. From 1993 to 2004, the numbers of adults in the subcolonies were counted 1 to 92 times during the early egg laying period through the early fledging period (days of the year 159 to 221), with the number of counts 
depending on the accessibility of the counting location and observation effort. Counts taken at any one time may have included incubating or brooding adults, offduty parents and non-breeders. Regular observations were not possible because observers were present on the island only periodically throughout the summer. However, there is no significant correlation $(\mathrm{r}=0.13$, $p=0.11$ ) between the mean number of murres counted and the number of times counts were made. Limited observations also occurred in 1991 and 1992, but were not used in this study because subcolonies were not enumerated.

Within this dataset, we defined subcolony colonization events as occurrences of murres in areas in which they were absent during the previous year. Thus, we considered colonizations from 1994 on, after confirming the sites had not been attended in 1993. We did not require observations of breeding to consider an area colonized because eggs can be laid and lost to predators within minutes; hence, failed breeding attempts can be difficult to verify without nearly constant observations. Of the 71 subcolony sites identified on Tatoosh Island as of 2004, 20 were founded between 1994 and 2004. However, not all have persisted. Subcolony persistence was defined operationally by murre occupation in the following year, and extinction was defined as any year following occupation when the average number of murres observed during the year was $<1$. Given that 1 murre of a breeding pair is generally in attendance at the nest site through a breeding season, and single pairs of murres have been recorded nesting removed from other pairs (J. Parrish, unpubl. data), we considered consistent attendance of 1 murre to be the minimum size for an extant subcolony. We were primarily interested in colonization patterns and so did not analyze extinctions of the 24 subcolonies that were in existence at the start of our study period and for which we did not know the colonization year or starting population size.

Factors influencing subcolony colonizations. We hypothesized 3 categories of factors that might have influenced colonization patterns by acting on potential colonizers in advance of the breeding season when they might be in the process of settling: (1) environmental conditions acting through the prey base (i.e. bottom-up forcing); (2) predator disturbance (i.e. topdown forcing); and (3) the pool of potential colonizers (i.e. demographic forcing).

Murres can forage as far away as $80 \mathrm{~km}$ from their colony during the breeding season (Ainley et al. 2002), so we assumed that all of the murres nesting on Tatoosh Island had access to the same prey resources. Much of the diet of breeding murres is composed of forage fish (Ainley et al. 2002), whose density offshore of the Washington coast varies annually and seasonally in response to environmental conditions (Brodeur et al. 2005, Emmett et al. 2006). Murres on Tatoosh Island consume 4 to 5 species, in 2 or more age classes, which collectively represent $\sim 80$ to $90 \%$ of the total biomass in their diet (J. Parrish unpubl. data). Thus, we identified a proxy to represent the annual variability in ocean productivity that might influence the total biomass of the murres' prey base, rather than make a specific prediction about the cohort strength of a particular species. The spring transition occurs on the date when winter oceanic conditions dominated by high sea level and coastal downwelling change to spring conditions characterized by low sea level and coastal upwelling. A 1 mo delay can result in depressed primary productivity and low recruitment of rocky intertidal organisms (Barth et al. 2007). The timing of the spring transition directly affects plankton and piscivorous fish, both of which influence forage fish distribution and abundance within a season (Emmett et al. 2006), and has been successfully used to predict coho salmon Oncorhynchus kisutch production in the Pacific Northwest (Logerwell et al. 2003). In addition, the abundance of forage fishes show a 1 yr lag between changing oceanographic conditions and increasing densities, reflecting the response of shortlived forage fish to changing ocean conditions by changing recruitment patterns (Emmett et al. 2006). To capture oceangraphic influence on prey fish populations, we included the spring transition immediately preceding the breeding season (Spring transition t) as well as spring transition in the preceding year (Spring transition $\mathrm{t}-1$ ) as proxies for ocean productivity. We tested the hypothesis that bottom-up forcing might influence colonizations such that when marine conditions were favorable, more murres would settle in new subcolonies. In particular, we expected that earlier transitions to upwelling conditions would promote increased prey abundance resulting in a higher proportion of the murre population attempting to breed in the following summers.

Murre subcolonies are likely to experience differing levels of predator pressure due to differences in the protection offered by the topology of the nesting areas as well as individual predator behavior. We hypothesized that high disturbance during the previous breeding season at Tatoosh Island might discourage murres that had been prospecting from settling in new subcolonies in the following year. We used an island-wide measure of predator (bald eagle) disturbance because data were not available at the level of the subcolony. Bald eagles are the murres' main predator at Tatoosh Island and visit the island daily during the breeding season from nesting and roosting locations on the mainland (Parrish et al. 2001). During any of the 8 to 10 trips lasting approximately 3 to $5 \mathrm{~d}$ to the island the highest 
number of bald eagles seen at one time in each year was recorded from late winter through summer. We used the mean of these maximum counts collected each year to represent annual predator pressure (Eagles).

We hypothesized that increasing numbers of murres on the island may influence prospecting murres to settle in new subcolonies on Tatoosh Island by (1) functioning as an attractant (public information) to the island as a whole and/or (2) fully occupying established subcolonies, leaving no space for additional murres. Murre attendance on Tatoosh Island is estimated annually from counts, corrected for the time of the counts and unobserved areas (Parrish et al. 2001). We used the annual change in murre attendance from the preceding year to represent demographic forcing (Population growth).

For the analysis of factors influencing colonization, we considered the colonization or lack of colonization of an 'available' subcolony area each year as the dependent variable. A subcolony was considered available if it was known to be occupied in another year, including a future year, but was empty in the current year. We used general linear models (GLM) with binomial error to test the effects of annual environmental conditions, predator disturbance and demographics on the occurrence of colonizations. Years in which a subcolony persisted following colonization were ignored (but see next section). Mixed models, in which a subcolony effect was treated as a random effect, were considered, but not used for final analyses because the random effects were negligible (variance $=<0.001)$. Candidate models were compared using Akaike's Information Criteria (AICc) corrected for small sample sizes (Burnham \& Anderson 2002).

Factors influencing subcolony persistence. We hypothesized that the persistence of the subcolonies established since 1994 might have been influenced by (1) their starting population size or (2) the starting population size in relation to the amount of nesting habitat available in the subcolony. Analyses were conducted independent of calendar year because the sample sizes could not support testing the influence of annualized factors, such as environmental or predator variables, on subcolony persistence. Therefore, we simply tested the hypothesis that the absolute number of murres in the year of colonization would influence persistence. We expected that subcolonies starting out larger would be more likely to persist because the benefits of colonial nesting increase as group size increases (the costs of colonial nesting notwithstanding) and demographic effects should lead to higher persistence of larger groups in this highly site-faithful species (Clode 1993). Alternatively, we thought that the benefits of colonial nesting might manifest themselves differently depend- ing on how 'full' the available nesting area was when the subcolony began. Physical space available for a new subcolony to expand into varies on Tatoosh Island depending on the topology of the rock ledge. For example, we thought that a group of 10 murres that began to occupy a space that could fit only 5 pairs might persist differently than a group of 10 murres that began to occupy a space that could hold 50 pairs (Birkhead 1977, 1978). Thus, we tested the hypothesis that subcolony persistence was related to how close the starting population size was to the apparent carrying capacity, operationally defined as the maximum annual subcolony size across all study years, within the subcolony area.

We treated each colonization event as independent for the analysis of subcolony persistence regardless of whether there were multiple colonizations over time at a single location. For each colonization event, we defined the starting population size as the mean number of murres counted in the year of colonization, and the carrying capacity of the site as the greatest number of murres counted during any of the counts in any year in that subcolony site.

Persistence data were analyzed using regressions for parametric survival models, specified with the survreg function in R (R Development Core Team 2005). Survival analysis treats the time to death (in this case, years to subcolony extinction) as the response variable. The survival function gives the probability that a subcolony will persist past time $t$ :

$$
S(t)=\operatorname{Pr}(T>t)
$$

where $T$ denotes the response variable. Exponential error distributions were chosen to estimate the survival distribution because they produced the minimum error deviance (Crawley 2002) when compared with extreme, logistic and Weibull distributions. The exponential error distribution assumes that there is a constant proportion of subcolony extinctions over time $t$. Subcolony survival is defined as:

$$
S(t)=\exp \{-[\exp (-\alpha+\beta x)] t\}
$$

where $\alpha$ and $\beta$ are the estimated parameters, and $x$ is the starting population size or the fraction that the starting population size is of the proxy for the carrying capacity. Data were considered censored (sensu Venables \& Ripley 1999) if the subcolony persisted through the end of the study period and, thus, the time to extinction was unknown. We used AICc to compare model fits among 3 models: (1) one with an influence of the starting population size, (2) one with an influence of the starting population size in relation to the carrying capacity of the subcolony area and (3) a null model that predicted average survival irrespective of starting population size. 


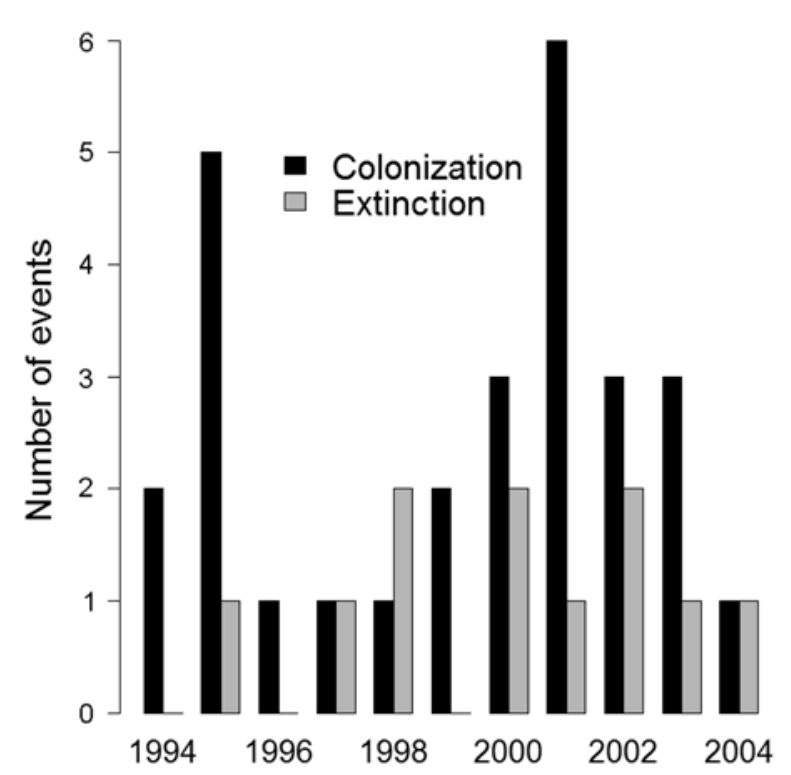

Fig. 1. Uria aalge. Number of colonizations and subsequent extinctions of new common murre subcolonies from 1994 to 2004. Previous observations in 1991 to 1993 proved that the colonizations in 1994 were new attempts

\section{RESULTS}

We identified 28 separate colonization events in the 20 subcolonies that were established after 1993. Colonizations occurred in every year (Fig. 1), with notable peaks in 1995 and 2001. Extinctions also occurred, albeit at a lower frequency. As colonizations occurred, the number of sites we considered available for colonization decreased because sites that were colonized in any year of our study were considered available before colonization and following extinction.

The starting population sizes of the new subcolonies ranged widely (1 to 212 murres) (Fig. 2). However, most subcolonies had few murres attending in their first year. Only 5 subcolonies had starting population sizes of $\geq 20$ murres. The largest colonization occurred in 1995, when 256 murres were observed on a ledge

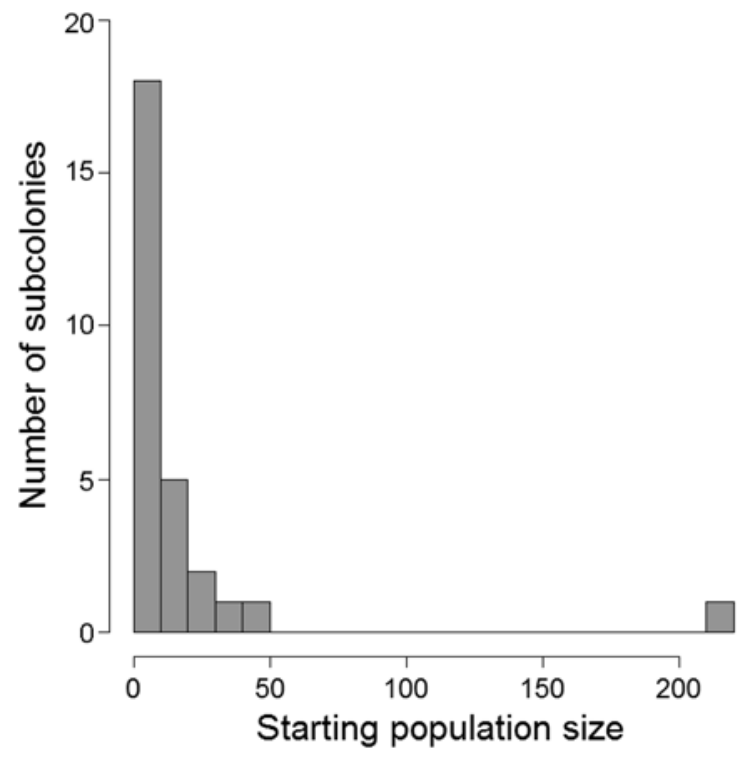

Fig. 2. Uria aalge. Distribution of the number of common murres in subcolonies in the year they were established. Each bar represents the total number of subcolonies of similar sizes when grouped into 10-murre bins

where they had not been seen previously. Subsequent counts confirmed that the ledge was attended regularly throughout that season. Eight colonization events were associated with a single observation, but only 1 observation included a single murre. The mean $( \pm \mathrm{SE})$ number of murres counted during these events was $5.4 \pm 2.1$. Five subcolony areas had multiple colonization events, defined as years with no murres observed interspersed with years with murres.

\section{Factors influencing subcolony colonizations}

Environmental conditions representing bottom-up forcing best explained the observed number of subcolony colonizations (Table 1). The date of the spring transition in the year prior to the colonization year

Table 1. Hypotheses and models for analysis of factors influencing subcolony colonization where $k$ is the number of parameters in the model

\begin{tabular}{|c|c|c|}
\hline Hypothesis & $k$ & $\triangle \mathrm{AICc}$ \\
\hline Bottom-up forcing as mediated through prey year class 1 (Spring transition $t-1$ ) & 2 & 0 \\
\hline Bottom-up forcing as mediated through prey year classes 1 and 0 (Spring transition $t-1+$ Spring transition $t$ ) & 3 & 0.1 \\
\hline Bottom-up and demographic forcing (Spring transition t-1 + Population growth) & 3 & 1.9 \\
\hline Bottom-up as mediated through prey year class 0 (Spring transition t) & 2 & 3.8 \\
\hline Demographic forcing (Population growth) & 2 & 6.3 \\
\hline Top-down forcing as mediated through predator disturbance in previous year (Eagles) & 2 & 9.6 \\
\hline
\end{tabular}



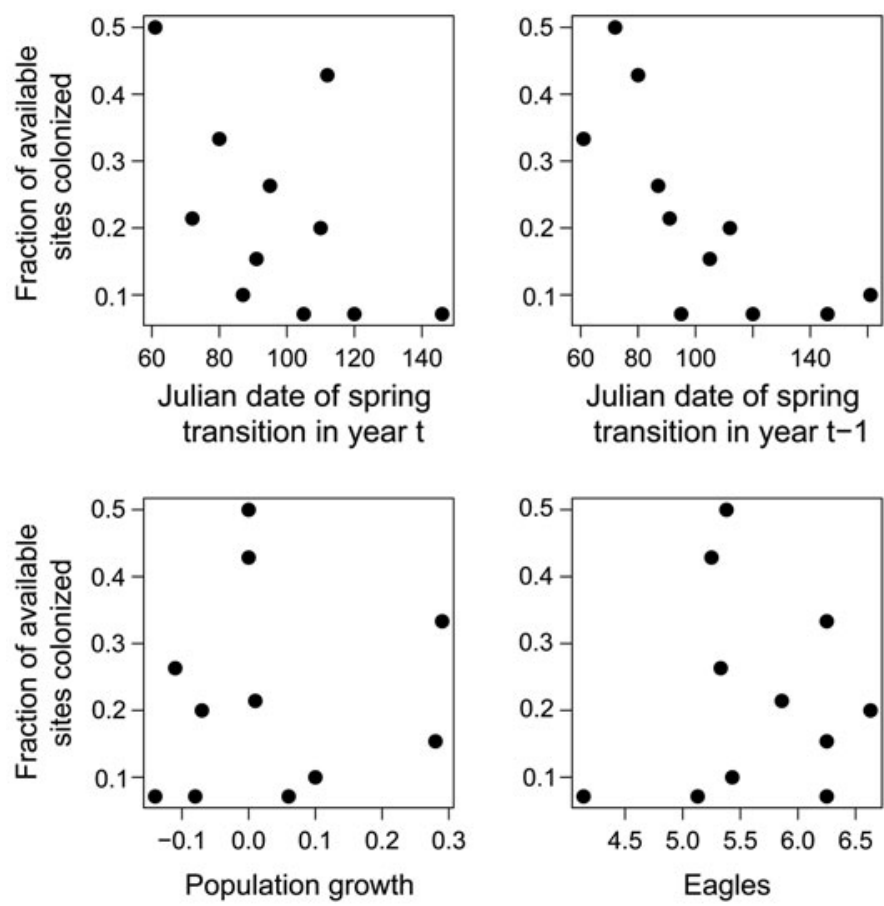

Fig. 3. Uria aalge. Proportion of available sites colonized in relation to the predictor variables used in the general linear model: the day of the year of the spring transition in Year $t$, spring transition in Year $\mathrm{t}-1$, population growth from Year $\mathrm{t}-1$ and a measure of eagle density in Year $\mathrm{t}-1$

(Spring transition t-1) was significantly and negatively correlated with the proportion of available sites that were subsequently colonized each year $(r=-0.74, p<$ 0.01, Fig. 3), supporting the notion that earlier dates of spring transition would promote more colonization attempts. The date of the spring transition in the year of colonization (Spring transition $\mathrm{t}$ ) was also negatively correlated with the proportion of available sites colonized, but was only marginally significant ( $\mathrm{r}=-0.54$, $\mathrm{p}=0.08$ ). Accordingly, the model with Spring transition thad less support for explaining colonizations than did the Spring transition $\mathrm{t}-1$ model $(\Delta \mathrm{AICC}=3.8$, Table 1). The model that included the dates of spring transition from both the current year and the year before colonization attempts had essentially the same support as the model selected using AICc, as indicated by a $\triangle \mathrm{AICc}$ of 0.1 (Table 1), further indicating that Spring transition $\mathrm{t}$ added little explanatory power. These results changed negligibly when colonization events consisting of single observations were excluded from the analyses.

Population growth rates varied from positive to negative almost annually (Fig. 4), with notably higher rates of increase in the later years of the study. However, demographic forcing had no apparent effect on colo- nization (Table 1). The addition of demographic forcing to a model with Spring transition $t-1$ did not improve the model fit markedly $(\Delta \mathrm{AICC}=1.9)$. There was a positive, but not significant, correlation between the annual population growth rate and the proportion of available sites that were colonized $(r=0.50, p=0.12)$.

Finally, top-down forcing, represented by a measure of eagle density in the year prior to colonization attempts, had essentially no support from the data as an explanatory variable for colonization attempts (Table 1). There was no correlation between the proportion of available sites colonized and the annualized mean of maximum eagle counts during the previous field season $(\mathrm{r}=$ 0.07, $p=0.83$, Fig. 3). Both peak and lowest numbers of eagles occurred preceding years of few colonization attempts (Fig. 4).

\section{Factors influencing subcolony persistence}

Most of the subcolonies that had $\leq 10$ murres in their first year did not persist more than $3 \mathrm{yr}$ (Fig. 5). All of those that started with $\geq 20$ murres persisted longer. However, the subcolonies with the longest persistence history showed a range of starting population sizes (4 to 212 murres).

The mean annual persistence rate of all new subcolonies was 0.91. However, adding the influence of the starting population size of the new subcolonies best explained the observed patterns in subcolony persistence (Table 2). Persistence was positively related to the starting population size, but was only marginally significant (Table 3). On the other hand, the influence of the starting population size relative to the apparent carrying capacity of the subcolony was not supported by the data (Table 2). Predicted persistence rates of subcolonies increased with increasing starting population size until starting populations reached 100, after which there was essentially no effect (Fig. 6). Model predictions of persistence were close to the observed persistence patterns, with some overprediction of the number of subcolonies that started out small (1 to 10 murres) that would persist for at least $1 \mathrm{yr}$, and underpredictions of the number of small colonies that would persist at least 2 yr (Fig. 5).

\section{DISCUSSION}

More subcolony colonizations occurred on Tatoosh Island when oceanographic conditions in the previous year were characterized by earlier transitions from winter downwelling and high sea level patterns to 

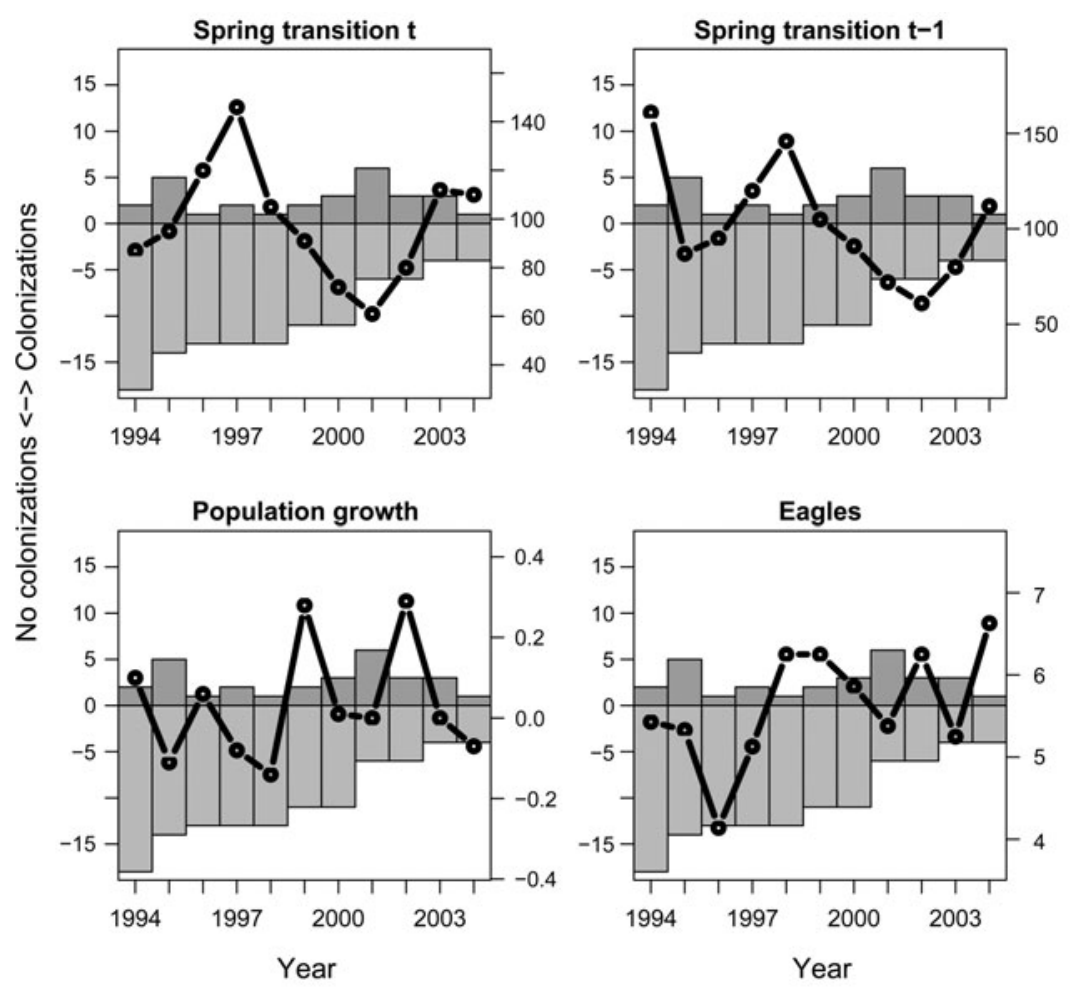

Fig. 4. Uria aalge. Number of available subcolonies with colonizations (upper bars) and no colonizations each year (lower bars) overlaid with the values for the environmental variables used to represent bottom-up, demographic and top-down forcing: the day of the year of the spring transition in Year $t$, spring transition in Year $t-1$, population growth from Year $t-1$, and a measure of eagle density in Year $\mathrm{t}-1$ tidal invertebrate recruitment (Barth et al. 2007). The pattern of increased murre subcolony colonization attempts in years following earlier dates of spring transition supports the finding of Emmett et al. (2006) that increased ocean productivity may have promoted strong year classes of forage fish in the following year, potentially creating a favorable foraging environment for many top predators, including murres. Weaker correlations between transition dates and colonization attempts in the same year may be explained by the delay in the trophic transfer from high primary productivity and zooplankton abundance to increased forage fish densities. However, the highest number of colonizations occurred in the same year as the earliest spring transition and the year following the second earliest. In summary, marine conditions characterized by early upwelling appeared to create an environment that encourages murres to settle in new areas.

Seabirds, murres in particular, are known to be susceptible to bottom-up forcing (Ainley et al. 1995, Barrett \& Krasnov 1996, Barrett 2002, Frederiksen et al. 2004). For example, mass mortality spring upwelling and low sea level patterns. Seasonally dominated upwelling systems, such as the California Current System-in which Tatoosh Island is located-are typified by high primary productivity, which serves as the basis for rich food webs (Mann \& Lazier 1996). Locally, earlier transition dates have been correlated with higher marine survival of Pacific salmon smolts (Ryding \& Skalski 1999, Logerwell et al. 2003), whereas later transition dates have been associated with decreased primary productivity and inter-

Fig. 5. Uria aalge. Distribution of common murre subcolonies starting population sizes for those that persisted $1,2,3,4,5$ and 6 or more years (bars). Points represent survival model predictions given the starting populations of new subcolonies. Squares represent model predictions given no effect of starting population size
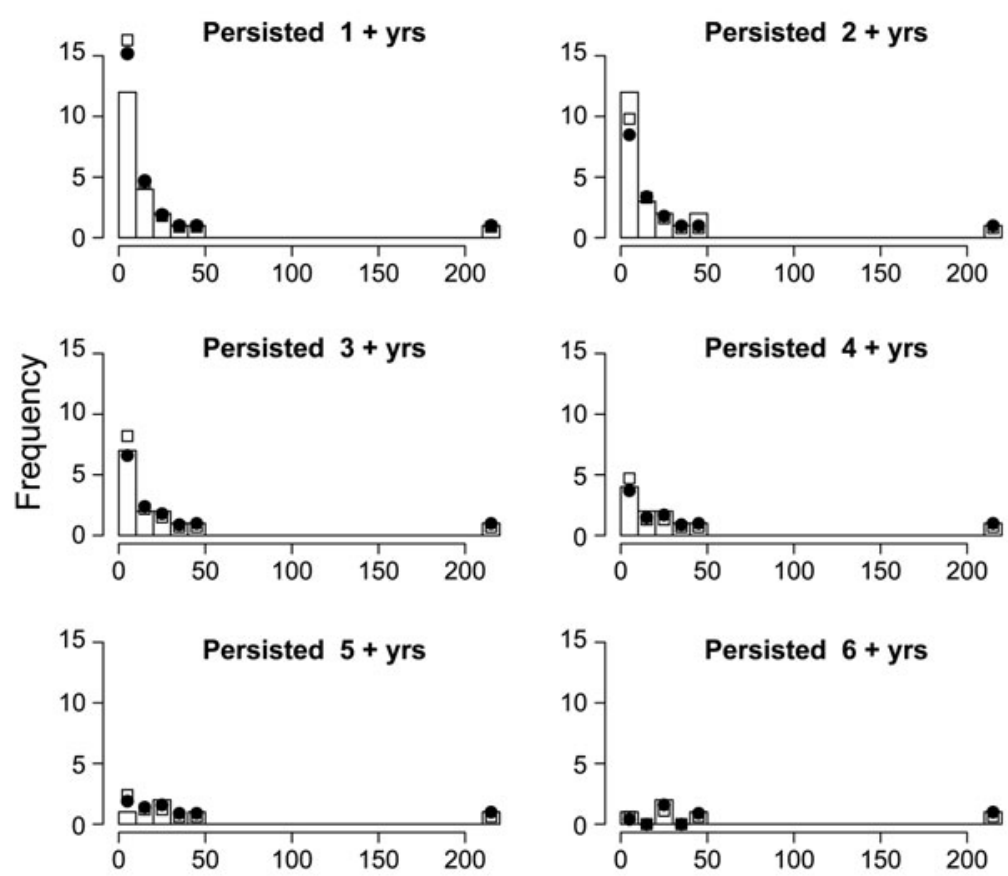

Starting population size 
of shearwaters was observed in the Bering Sea after a period of low euphausiid availability (Napp \& Hunt 2001) and of murres in the Gulf of Alaska following presumed reduced food availability (Piatt \& Van Pelt 1997). Murre populations, and their reproductive success, behavior and phenology have been previously associated with local and regional environmental indicators (Oedekoven et al. 2001, Sydeman et al. 2001, Reed et al. 2006), as well as with direct measures of

Table 2. Model fits for analysis of factors influencing subcolony persistence where $k$ is the number of parameters in the model. The apparent carrying capacity was determined as the greatest number of murres counted in any year at the site. The null model calculates the average survival rates for all new subcolonies

\begin{tabular}{|lcc|}
\hline Factors & $k$ & $\Delta$ AICc \\
\hline Starting population & 2 & 0 \\
Null model & 1 & 5.1 \\
Starting population size in relation & 2 & 6.6 \\
to apparent carrying capacity & & \\
\hline
\end{tabular}

Table 3. Parameter estimates for the model representing subcolony persistence as a function of the starting population size

\begin{tabular}{|lcccc|}
\hline Coefficients & Value & $\mathrm{SE}$ & $Z$ & $\mathrm{p}$ \\
\hline Intercept & 1.49 & 0.40 & 3.73 & $<0.0001$ \\
Starting population size & 0.06 & 0.04 & 1.84 & 0.07 \\
\hline
\end{tabular}

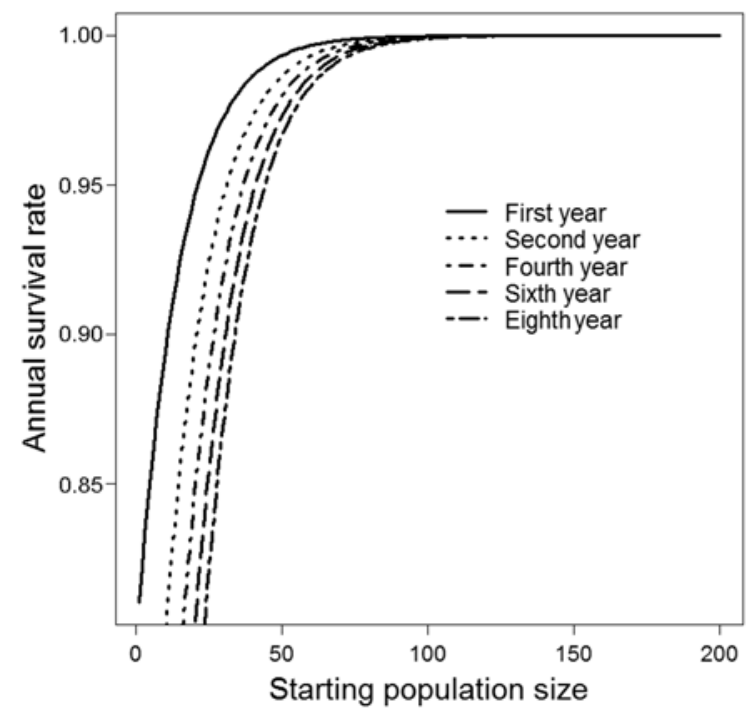

Fig. 6. Uria aalge. Annual survival rate (persistence) of subcolonies in their first to eighth years given their starting population size their food supply (Monaghan et al. 1994, Uttley et al. 1994, Zador \& Piatt 1999, Kitaysky et al. 2000).

Our proxies for top-down and demographic forcing did not explain colonization patterns to any significant degree. However, the island-wide measure of eagle abundance may have obscured the effects of differential predation pressure because individual murre nesting areas have varying levels of exposure to eagles resulting from variations in cliff topology. Predation rates are known to vary with site characteristics, and differences can even occur on a fine scale within ledges (Steiner \& Gaston 2005). With the loss of the single largest exposed subcolony located on an open cliff top in 1995 (extant at the beginning of our study) due to heavy eagle disturbance (Parrish \& Paine 1996), most of the remaining cliff-ledge subcolonies afforded some sort of physical protection from eagles via rocky overhangs. This event coincided with the second highest number of subcolony colonizations, suggesting that murres redistributed themselves to new cliff-side subcolonies. In addition, overall eagle abundance is probably an imperfect measure of predation pressure because the amount of predation pressure felt by murres is influenced by both the individual eagle activity level and overall eagle abundance, i.e. murres probably do not distinguish between repeated disturbance by a single eagle or single disturbance events by multiple eagles (Parrish et al. 2001). The lack of a relationship between eagle abundance and colonization attempts resulted in the top-down forcing model fitting least well among the models we examined.

However, the relationship, albeit not significant, between annualized murre population growth and colonizations suggests that when the population increased from the previous year, murres settled in new areas. This relationship would be expected if either an increase in murres required an increase in nesting locations (a spillover effect) or if the increase in murres provided positive public information (Valone \& Templeton 2002), encouraging more conspecifics to settle via social attraction (Serrano et al. 2004). Testing specific social attraction hypotheses, such as the influence of differential attendance of individuals (e.g. failed breeders or prospecting pre-breeders) within the previous breeding season, would require individually marked birds, but may clarify the relationship between population trends and colonizations. Nevertheless, the use of public information is predicted to occur especially in species with high nesting density, high survival and open nests (Doligez et al. 2002, Boulinier et al. 2008). Such processes are probably occurring because murres show all of these traits (but see Kokko et al. 2004).

Our analysis indicated that subcolonies initialized by few murres were more likely to be abandoned shortly 
thereafter. In contrast, larger subcolonies are more likely to persist. This follows the contention that nesting in groups provides some advantage, leaving small groups at a disadvantage and, therefore, more ephemeral (Danchin \& Wagner 1997). In this study, the predicted persistence rate of subcolonies that started with >100 murres was almost 1. Although we observed only one large colonization, the results of our persistence analysis remained unchanged when this subcolony was excluded indicating that the analysis was not unduly influenced by this single event. However, we also know that some large subcolonies do go extinct, as was observed in the large exposed cliff-top subcolony mentioned above. In this case, the extinction was preceded by a rapid decline in the productivity of the subcolony, attributed to increased eagle disturbance, indicating that predators can have an effect on subcolony persistence (Parrish \& Paine 1996).

We assume that the observations captured murre attendance patterns without great bias because we found no correlation between observation effort and the number of murres counted. However, as attendance at new colonies can be sporadic, the ability to establish patterns may be compromised by infrequent observations, making detection probabilities a concern. Patch occupancy models that account for detection probabilities < 1 may be promising for modeling subcolony dynamics in future studies with robust data collection designs that include surveying currently unoccupied areas (MacKenzie et al. 2003). In addition, tracking movements of individually marked birds among multiple subcolony sites may allow for estimation of individual detection probabilities through capture-mark-recapture models (Cam et al. 1998, Oro et al. 2004). In this study, it is unlikely that murres had previously colonized many of the areas in which colonizations occurred after 1993. Prior to 1991, the total murre population on Tatoosh Island was relatively smaller than it was during this study (Parrish \& Paine 1996). In addition, all of the subcolonies areas in our analysis were available during the first 3 or more years of observation. However, there is the potential that some subcolonies recorded as extinct may have had sporadic attendance that went undetected. In this case, subcolony persistence would have been underestimated. However, observations of zero murres in a subcolony during the peak of the breeding season indicate that no successful breeding could have taken place and that the area was only occupied sporadically at best.

The results of this study support the theory that the proportion of the entire murre population that attempts to breed in a given year is higher in years with favorable environmental conditions. Population dynamics of southern fulmars Fulmarus glacialoides are strongly influenced by the variability in the proportion of breeders, which has been linked to variability in seaice extent (Jenouvrier et al. 2005). Probabilities of individual murres returning to colonies in Scotland in a given year have been found to be positively correlated with the North Atlantic oscillation index (Crespin et al. 2006a). Murres use poorer quality sites in years when population densities are higher, thereby decreasing colony-wide mean reproductive success (Kokko et al. 2004). If we assume more sites are occupied during years with favorable environmental conditions, increasing numbers of subcolonies may be sensitive indicators of environmental conditions. In years with unfavorable environmental conditions, we would expect murres to continue to occupy established high quality sites as experienced breeders are able to buffer the effects of moderate to poor foraging conditions (Burger \& Piatt 1990, Ainley et al. 2005). Indeed, the most productive individual murre nesting sites have longer occupation histories (Kokko et al. 2004). It is in the newly colonized or frequently re-colonized areas where we would most expect to see a relationship with environmental conditions (as was seen in this analysis).

It is important to keep in mind that population processes are influenced by the relative effects of factors affecting breeding probability, reproductive success and annual survival and that these are known to differ across spatial and temporal scales. For example, Parrish et al. (2001) found both direct and indirect effects of eagle predation to be the driving factors influencing Tatoosh Island murre population dynamics except in occasional years when climatic effects swamped those of predation. Similarly, successful kittiwake dispersal strategies have been found to vary depending on temporal trends in parasitism and the response of kittiwakes to that parasitism (Boulinier \& Lemel 1996). Nevertheless, it is expected that some combination of bottom-up, top-down and demographic forcing will remain important influences at a variety of scales on population processes, such as subcolony colonizations, in coastal nesting seabirds such as murres.

The results from our study could help to better predict the success of management actions such as social attraction or habitat modification for restoration. Murres rapidly recolonized Devil's Slide Rock in California, where murres had not bred for a decade, after social attractants were deployed (Parker et al. 2007). Coincident with this success was the beginning of a phase of cooler water, indicating that environmental conditions may have contributed favorably to the murre recolonization (Oedekoven et al. 2001). We predict the results of comparable management actions may vary with marine conditions, such that planning management actions during or following years of favorable marine conditions may enhance success. Also we pre- 
dict that the more murres that attempt to colonize a new area in the initial year, the more likely it is that the colony or subcolony will persist. Increased knowledge of murre colony formation may help scientists and managers understand the potential for recolonizations after colony extirpations (Riffaut et al. 2005).

Acknowledgements. We gratefully acknowledge the efforts of C. French, N. Hamel and many others who collected data on murres on Tatoosh Island, and R. Paine, who generously provided data on eagle counts. We thank the Makah Indian Nation, who granted us permission to work on Tatoosh Island. Comments from D. Ainley and 3 anonymous reviewers helped to improve the manuscript. S.G.Z. was funded in part by the Tenyo Maru Trustee Council and the University of Washington, School of Aquatic and Fishery Sciences.

\section{LITERATURE CITED}

Ainley DG, Boekelheide RJ (1990) Seabirds of the Farallon Islands: ecology, dynamics, and structure of an upwellingsystem community. Stanford University Press, Stanford, CA

Ainley DG, Sydeman WJ, Norton J (1995) Upper trophic level predators indicate interannual negative and positive anomalies in the California Current food-web. Mar Ecol Prog Ser 118:69-79

Ainley DG, Nettleship DN, Carter HR, Storey AE (2002) Common Murre (Uria aalge). In: Poole A, Gill F (eds) The birds of North America. The Birds of North America, Philadelphia, PA, p 44

Ainley DG, Clarke ED, Arrigo K, Fraser WR, Kato A, Barton KJ, Wilson PR (2005) Decadal-scale changes in the climate and biota of the Pacific sector of the Southern Ocean, 1950s to the 1990s. Antarct Sci 17:171-182

Anderson DJ, Hodum PJ (1993) Predator behavior favors clumped nesting in an oceanic seabird. Ecology 74 : $2462-2464$

Antolos M, Roby DD, Lyons DE, Anderson SK, Collis K (2006) Effects of nest denity, location, and timing on breeding success of Caspian Terns. Waterbirds 29:465-472

Barrett RT (2002) Atlantic puffin Fratercula arctica and common guillemot Uria aalge chick diet and growth as indicators of fish stocks in the Barents Sea. Mar Ecol Prog Ser 230:275-287

Barrett RT, Krasnov YV (1996) Recent responses to changes in stocks of prey species by seabirds breeding in the southern Barents Sea. ICES J Mar Sci 53:713-722

Barth JA, Menge BA, Lubchenco J, Chan F and others (2007) Delayed upwelling alters nearshore coastal ocean ecosystems in the northern California current. Proc Natl Acad Sci USA 104:3719-3724

Birkhead TR (1977) Effect of habitat and density on breeding success in Common Guillemot (Uria aalge). J Anim Ecol 46:751-764

Birkhead TR (1978) Behavioural adaptations to high density nesting in the Common Guillemot Uria aalge. Anim Behav 26:321-331

Boulinier T, Lemel JY (1996) Spatial and temporal variations of factors affecting breeding habitat quality in colonial birds: some consequences for dispersal and habitat selection. Acta Oecol 17:531-552

Boulinier T, McCoy KD, Yoccoz NG, Gasparini J, Tveraa T (2008) Public information affects breeding dispersal in a colonial bird: kittiwakes cue on neighbours. Biol Lett 4: 538-540

Brodeur RD, Fisher JP, Emmett RL, Morgan CA, Casillas E (2005) Species composition and community structure of pelagic nekton off Oregon and Washington under variable oceanographic conditions. Mar Ecol Prog Ser 298:41-57

Brown CR, Brown MB (2001) Avian coloniality: progress and problems. In: Nolan V Jr (ed) Current ornithology, Vol 16. Kluwer Academic/Plenum Publishers, New York, p 1-82

Buckley NJ (1997) Spatial-concentration effects and the importnace of local enhancement in the evolution of colonial breeding in seabirds. Am Nat 149:1091-1112

Burger AE, Piatt JF (1990) Flexible time budgets in breeding Common Murres: buffers against variable prey abundance. Stud Avian Biol 14:71-83

Burnham KP, Anderson DR (2002) Model selection and multimodel inference: a practical information-theoretic approach. Springer, New York

Cam E, Hines JE, Monnat JY, Nichols JD, Danchin E (1998) Are adult nonbreeders prudent parents? The Kittiwake model. Ecology 79:2917-2930

> Clode D (1993) Colonially breeding seabirds: Predators or prey? Trends Ecol Evol 8:336-338

Crawley MJ (2002) Statistical computing: an introduction to data analysis using S-Plus. John Wiley and Sons, Chichester

Crespin L, Harris MP, Lebreton JD, Frederiksen M, Wanless S (2006a) Recruitment to a seabird population depends on environmental factors and on population size. J Anim Ecol 75:228-238

Crespin L, Harris MP, Lebreton JD, Wanless S (2006b) Increased adult mortality and reduced breeding success with age in a population of common guillemot Uria aalge using marked birds of unknown age. J Avian Biol 37: 273-282

Danchin E, Wagner RH (1997) The evolution of coloniality: the emergence of new perspectives. Trends Ecol Evol 12: 342-347

Danchin E, Bouliner T, Massot M (1998) Conspecific reproductive success and breeding habitat selection: implications for the study of coloniality. Ecology 79:2415-2428

Davoren GK, Montevecchi WA, Anderson JT (2003) Search strategies of a pursuit-diving marine bird and the persistence of prey patches. Ecol Monogr 73:463-481

> Doligez B, Danchin E, Clobert J (2002) Public information and breeding habitat selection in a wild bird population. Science 297:1168-1170

> Emmett RL, Krutzikowsky GK, Bentley P (2006) Abundance and distribution of pelagic piscivorous fishes in the Columbia River plume during spring/early summer 1998-2003: relationship to oceanographic conditions, forage fishes, and juvenile salmonids. Prog Oceanogr 68: $1-26$

Frederiksen M, Harris MP, Daunt F, Rothery P, Wanless S (2004) Scale-dependent climate signals drive breeding phenology of three seabird species. Glob Change Biol 10: $1214-1221$

Halley DJ, Harris MP, Wanless S (1995) Colony attendance patterns and recruitment in immature common murres (Uria aalge). Auk 112:947-957

Hario M (1982) On the size and recruitment of a peripheral breeding colony of the Guillemot (Uria aalge). Ornis Fenn 59:193-194

> Harris MP, Wanless S (1995) Survival and non-breeding of adult Common Guillemots Uria aalge. Ibis 137:192-197

> Harris MP, Halley DJ, Wanless S (1992) The postfledging survival of young Guillemots Uria aalge in relation to hatch- 
ing date and growth. Ibis 134:335-339

Harris MP, Wanless S, Barton TR (1996) Site use and fidelity in the Common Guillemot Uria aalge. Ibis 138:399-404

Harris MP, Wanless S, Barton TR, Elston DA (1997) Nest site characteristics, duration of use and breeding success in the Guillemot Uria aalge. Ibis 139:468-476

> Hatchwell BJ, Birkhead TR (1991) Population dynamics of Common Guillemots Uria aalge on Skomer Island, Wales. Ornis Scand 22:55-59

Jenouvrier S, Barbraud C, Cazelles B, Weimerskirch H (2005) Modelling population dynamics of seabirds: importance of the effects of climate fluctuations on breeding proportions. Oikos 108:511-522

Kitaysky AS, Hunt GL, Flint EN, Rubega MA, Decker MB (2000) Resource allocation in breeding seabirds: responses to fluctuations in their food supply. Mar Ecol Prog Ser 206: 283-296

Kokko H, Harris MP, Wanless S (2004) Competition for breeding sites and site-dependent population regulation in a highly colonial seabird, the common guillemot Uria aalge. J Anim Ecol 73:367-376

> Logerwell EA, Mantua N, Lawson PW, Francis RC, Agostini VN (2003) Tracking environmental processes in the coastal zone for understanding and predicting Oregon coho (Oncorhynchus kisutch) marine survival. Fish Oceanogr 12:554-568

MacKenzie DI, Nichols JD, Hines JE, Knutson MG, Franklin AB (2003) Estimating site occupancy, colonization, and local extinction when a species is detected imperfectly. Ecology 84:2200-2207

Mann KH, Lazier JRN (1996) Dynamics of marine ecosystems. Blackwell Science, Cambridge, MA

Martinez-Abrain A, Oro D, Forero MG, Conesa D (2003) Modeling temporal and spatial colony-site dynamics in a long-lived seabird. Popul Ecol 45:133-139

McCoy KD, Chapuis E, Tirard C, Boulinier T and others (2005) Recurrent evolution of host-specialized races in a globally distributed parasite. Proc R Soc Lond B Biol Sci 272:2389-2395

Monaghan P, Walton P, Wanless S, Uttley JD, Burns MD (1994) Effects of prey abundance on the foraging behavior, diving efficiency and time allocation of breeding Guillemots Uria aalge. Ibis 136:214-222

Napp JM, Hunt GL (2001) Anomalous conditions in the southeastern Bering Sea 1997: linkages among climate, weather, ocean, and biology. Fish Oceanogr 10:61-68

Oedekoven CS, Ainley DG, Spear LB (2001) Variable responses of seabirds to change in marine climate: California Current, 1985-1994. Mar Ecol Prog Ser 212:265-281

Oro D, Ruxton GD (2001) The formation and growth of seabird colonies: Audouin's gull as a case study. J Anim Ecol 70:527-535

> Oro D, Cam E, Pradel R, Martinez-Abrain A (2004) Influence of food availability on demography and local population dynamics in a long-lived seabird. Proc R Soc Lond B Biol Sci 271:387-396

Paine RT, Wootton JT, Boersma PD (1990) Direct and indirect effects of peregrine falcon predation on seabird abundance. Auk 107:1-9

Parker MW, Kress SW, Golightly RT, Carter HR and others (2007) Assessment of social attraction techniques used to restore a Common Murre colony in central California. Waterbirds 30:17-28

Parrish JK (1995) Influence of group size and habitat type on reproductive success in common murres (Uria aalge). Auk 112:390-401
Parrish JK, Paine RT (1996) Ecological interactions and habitat modification in nesting Common Murres, Uria aalge. Bird Conserv Int 6:261-269

> Parrish JK, Marvier M, Paine RT (2001) Direct and indirect effects: interactions between bald eagles and common murres. Ecol Appl 11:1858-1869

Phillips RA, Furness RW, Stewart FM (1998) The influence of territory density on the vulnerability of Arctic skuas Stercorarius parasiticus to predation. Biol Conserv 86:21-31

Piatt JF, Van Pelt TI (1997) Mass-mortality of Guillemots (Uria aalge) in the Gulf of Alaska in 1993. Mar Pollut Bull 34: $656-662$

> Pius SM, Leberg PL (2002) Experimental assessment of the influence of Gull-Billed Terns on nest site choice of Black Skimmers. Condor 104:174-177

R Development Core Team (2005) R: a language and environment for statistical computing. R Foundation for Statistical Computing, www.r-project.org/

Reed TE, Wanless S, Harris MP, Frederiksen M, Kruuk LEB, Cunningham EJA (2006) Responding to environmental change: plastic responses vary little in a synchronous breeder. Proc R Soc Lond B Biol Sci 273:2713-2719

> Riffaut L, McCoy KD, Tirard C, Friesen VL, Boulinier T (2005) Population genetics of the common guillemot Uria aalge in the North Atlantic: geographic impact of oil spills. Mar Ecol Prog Ser 291:263-273

Robson BW, Goebel ME, Baker JD, Ream RR and others (2004) Separation of foraging habitat among breeding sites of a colonial marine predator, the northern fur seal (Callorhinus ursinus). Can J Zool 82:20-29

Ryding KE, Skalski JR (1999) Multivariate regression relationships between ocean conditions and early marine survival of coho salmon (Oncorhynchus kisutch). Can J Fish Aquat Sci 56:2374-2384

Serrano D, Forero MG, Donazar JA, Tella JL (2004) Dispersal and social attraction affect colony selection and dynamics of lesser kestrels. Ecology 85:3438-3447

Steiner UK, Gaston AJ (2005) Reproductive consequences of natal dispersal in a highly philopatric seabird. Behav Ecol 16:634-639

Stokes DL, Boersma PD (2000) Nesting density and reproductive success in a colonial seabird, the magellanic penguin. Ecology 81:2878-2891

Sydeman WJ (1993) Survivorship of Common Murres on southeast Farallon Island, California. Ornis Scand 24: $135-141$

Sydeman WJ, Hester MM, Thayer JA, Gress F, Martin P, Buffa J (2001) Climate change, reproductive performance and diet composition of marine birds in the southern California Current system. Prog Oceanogr 49:309-329

Uttley JD, Walton P, Monaghan P, Austin G (1994) The effects of food abundance on breeding performance and adult time budgets of Guillemots Uria aalge. Ibis 136: 205-213

> Valone TJ, Templeton JJ (2002) Public information for the assessment of quality: a widespread social phenomenon. Philos Trans R Soc Lond B 357:1549-1557

Venables WN, Ripley BD (1999) Modern applied statistics with S-PLUS. Springer, New York

Wittenberger JF, Hunt GL Jr (1985) The adaptive significance of coloniality in birds. In: Farner DS, King JR, Parkes KC (eds) Avian biology, Vol 8. Academic Press, New York, p 1-78

Zador SG, Piatt JF (1999) Time-budgets of common murres at a declining and increasing colony in Alaska. Condor 101: $149-152$

Submitted: February 14, 2008; Accepted: October 24, 2008

Proofs received from author(s): January 29, 2009 